\title{
A Virtual Tissue Bank for Primary Central Nervous System Lymphomas in Immunocompetent Individuals
}

\author{
Maurilio Ponzoni ${ }^{a, d, e, h} \quad$ Ivo Kwee ${ }^{e, f}$ Luca Mazzucchellic, d, e \\ Andrés J.M. Ferreri ${ }^{b, d, e}$ Emanuele Zucca ${ }^{d, e}$ Claudio Doglioni ${ }^{a, h}$ \\ Franco Cavallid, e Francesco Bertoni ${ }^{d, e, g}$
}

Divisions of a Pathology and ${ }^{\mathrm{b}}$ Medical Oncology, Department of Oncology, San Raffaele Scientific Institute, Milan, Italy; ' Istituto Cantonale di Patologia, Locarno, ${ }^{d}$ International Extranodal Lymphoma Study Group and e Oncology Institute of Southern Switzerland, Bellinzona, and ${ }^{\mathrm{f} I s t i t u t o}$ Dalle Molle di Studi sull'Intelligenza

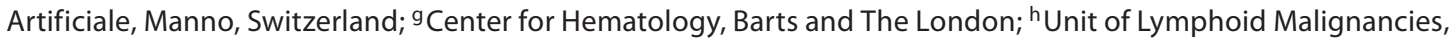
London, UK

\section{Key Words}

Biopsy • Brain tumor • Central nervous system • Lymphoma, primary • Non-Hodgkin lymphoma · Tissue sampling •

Virtual tissue bank

\begin{abstract}
Primary central nervous system lymphoma (PCNSL) is a rare form of extranodal non-Hodgkin's lymphoma with continuously increasing incidence in both immunosuppressed and immunocompetent individuals. PCNSL is a very aggressive tumor with a poor outcome, and its clinical outcome is much worse than for nodal lymphomas. Differently from lymphomas arising in lymph nodes or in other extranodal sites, the treatment of PCNSL remains very unsatisfactory. Current biologic knowledge of PCNSL is still limited and several fundamental questions remain to be answered. This is mainly due to the paucity of PCNSL material for adequate translational research. With the aim of providing biologic material to investigators interested in PCNSL, we have implemented a virtual tissue bank (VTB) for PCNSL in immunocompetent patients. After registration, the VTB is accessible via any web
\end{abstract}

browser at www.ielsg.org. Only anonymous data are centralized at the website of the International Extranodal Lymphoma Study Group, whilst the pathologic material is maintained at the local pathology institutes.

Copyright $\odot 2007$ S. Karger AG, Base

\section{Introduction}

Primary central nervous system lymphoma (PCNSL) accounts for $4 \%$ of all primary brain tumors and for $2-$ $10 \%$ of all primary extranodal lymphoma localizations $[1,2]$. Its incidence is increasing in both immunosuppressed patients and immunocompetent individuals. Usually, PCNSL arising in immunocompetent patients are Epstein-Barr virus-negative, diffuse, large, B-cell lymphomas (DLBCL). PCNSL is a very aggressive tumor with a clinical outcome much worse than for nodal lymphomas. The treatment of these malignancies remains very unsatisfactory: the overall survival is only $20-25 \%$ at 5 years.

\section{KARGER}

Fax +4161306 1234

E-Mail karger@karger.ch

www.karger.com (c) 2007 S. Karger AG, Basel

$1015-2008 / 07 / 0744-0264 \$ 23.50 / 0$

Accessible online at:

www.karger.com/pat
Dr. Maurilio Ponzoni

Pathology Unit, San Raffaele Scientific Institute

Via Olgettina 60

IT-20132 Milan (Italy)

Tel. +39 022643 2544, Fax +3902 2643 2409, E-Mail ponzoni.maurilio@hsr.it 


\section{Clinical Features of PCNSL}

The median age of PCNSL patients is 61 years (range 14-85 years). More than half of the patients present with a bad performance status (ECOG PS $>1$ ) and frequently display involvement of the frontal lobe; one third have multiple lesions. Deep brain structures (basal ganglia, corpus callosum, brainstem and cerebellum) are involved in $30-40 \%$ of cases. One third of the patients have lymphoma cells at cerebrospinal fluid (CSF) examination; $60 \%$ of the cases have an elevated concentration of CSF proteins. A prognostic scoring system has been proposed by the International Extranodal Lymphoma Study Group (IELSG) and is based upon the following factors: age $>60$ years, ECOG PS $>1$, elevated serum lactate dehydrogenase, high CSF protein levels and deep brain involvement [3]. The overall survival varies according to the combination of these parameters [3].

\section{Treatment of PCNSL}

Current therapeutic knowledge of PCNSL derives from retrospective multicenter studies, nonrandomized phase II trials and meta-analyses of published reports [3-9].

Surgery is not a treatment option in PCNSL, and whole-brain radiotherapy is rarely curative (median survival 12-14 months). The introduction of chemotherapy significantly improved prognosis. The single most active drug is high-dose (i.e. $>1 \mathrm{~g} / \mathrm{m}^{2}$ ) methotrexate (MTX). However, overall survival at 5 years is only $20-25 \%$, and the risk of late neurotoxicity, especially in the elderly, is increased in comparison with individual treatments. MTX has also been administered as combination therapy, and the 'standard' regimen for PCNSL employed may be an MTX-based combination chemotherapy.

\section{Pathology and Genetics of PCNSL}

In immunocompetent patients, more than $90 \%$ of PCNSL are DLBCL $[3-5,10]$, with rare exceptions [11, 12]. The lymphomatous tissue often contains a variable amount of reactive $\mathrm{T}$ cells.

PCNSL cells often express bcl-2, bcl-6 and MUM1 molecules, less frequently CD10 $[13,14]$. Thus, when they are compared to nodal DLBCL, they usually fall into the activated B-cell type. Compared to nodal non-Hodgkin's lymphomas, preliminary gene expression data available for PCNSL describe a preferential expression of molecules involved in the regulation of apoptosis or in the signaling pathway of unfolded protein response [15]. About half of PCNSL show alterations in the CDKN2A gene, thus leading to the failure to detect immunohistochemically its product p16 [16] and in p14 gene [17].

Cytogenetic characteristics correspond to those of 'extra-brain' DLBCL [18] but a higher incidence of chromosome $6 \mathrm{q}$ deletion is noted in PCNSL [19]. PCNSL cells have been reported to use preferentially individual VH3 [20] and VH4 gene families of the immunoglobulin heavy chain genes at DNA level, with somatic mutations and intraclonal heterogeneity [21]. This mechanism of aberrant somatic hypermutation involves additional genes, including PIM1, c-MYC, PAX5, RhoH/TTF, GSTP1, DAPK, TIMP-3, MGMT and THBS1 [22, 23].

\section{PCNSL and Immunology}

CNS and the eye [24-27] have been considered an immune sanctuary. Elements supporting this dogma are: (1) the blood-brain barrier; (2) the blood-CSF barrier; (3) the absence of lymphatic vessels; (4) the absence, at least in healthy conditions, of dendritic cells; (5) the high local production of anti-inflammatory mediators; (6) the constitutive FAS expression on those cells that induce the killing of immune cells, and (7) the presence of microglia, a specialized monocyte/macrophage population considered the main immune component of the CNS.

Different hypotheses have been put forward concerning PCNSL lymphomagenesis, with each of them lacking supporting data. PCNSL might derive from a systemic lymphoma, controlled by the systemic immune system with the exclusion of the brain, the immune sanctuary. Likewise, PCNSL might arise from a lymphocyte undergoing malignant transformation inside the brain trapped at CNS level.

\section{The Microenvironment in PCNSL}

The non-neoplastic immune system seems to be actively involved in PCNSL pathogenesis. Issues in favor of this hypothesis are the presence of reactive perivascular T-cell infiltration in a significant number of cases, where it has been related to a significantly more favorable outcome in PCNSL [28] and a low expression of HLA class I and II molecules in approximately half of PCNSL patients, a critical step predisposing to immune escape from 
cytotoxic T-cell activation [29-32]. PCNSL cells and vascular endothelium are a primary source of the B-cell-attracting chemokine 1 (BCA-1) [33], thus reinforcing the theory of a close interaction between lymphocytes and vessels; PCNSL tumor cells also express the selective BCA-1 receptor, CXCR5. BCA-1 is selective for B lymphocytes and follicular T-helper lymphocytes that are recruited with very high efficacy and a relatively low potency. In addition, tumors could express chemokines in order to subvert immune defense.

Finally, the recent demonstration of the presence of low amounts of B lymphocytes in normal brain opens new insights into the pathogenesis of PCNSL [34].

\section{Open Questions in PCNSL}

An IELSG-sponsored PCNSL workshop [5] pointed out several unanswered molecular and pathologic questions, such as the origin of PCNSL cells, a better definition of CNS as an immunologically privileged organ, the regulated neuroimmune network where the CNS is integrated, blood-brain barrier characteristics and tumor accessibility, and the prognostic role of biologic and molecular markers. At the same meeting, the International PCNSL Collaborative Group was founded [35]. For the first time ever, a 'global approach' by a group of worldwide specialists - including neurologists, oncologists, radiation oncologists, hematologists, pathologists, basic scientists and biostatisticians - was possible.

\section{Virtual Tissue Bank for PCNSL}

The establishment of tumor tissue banks appears therefore of paramount importance. Access to tumor material is fundamental to improve our knowledge about cancer and to ultimately improve the therapeutic results [36-41]. This is especially true for PCNSL, since one of the main limitations for research in this field has been the paucity of tumor material. This is due both to the rarity of the disorder and, perhaps more importantly, to the small size of biopsy specimens, which are usually obtained stereotactically and measure $2-5 \mathrm{~mm}$ in diameter. Therefore, an international, multi-institutional tissue bank is the only reasonable approach to overcome these problems. Of note, the collection of frozen PCNSL material is extremely important to allow future in-depth molecular studies.
The collaboration between the IELSG and the International PCNSL Collaborative Group resulted in the accumulation of data of both retrospective and prospective cases in VTB. VTB means that material is stored at local tumor banks or at local pathology departments, while data storage is centralized. Any pathologist can contribute to the VTB. The only requirement is the will to share the residual diagnostic tissue for future IELSG-approved studies on PCNSL. It is mandatory that the collection of the tissue for VTB will not affect the use of this sample for further diagnostic procedures for the patient. The contributing pathologist is free to perform his/her own studies on the same material independently of VTB, but it is his/her own responsibility to update the VTB Central Office if the tissue block of a patient is no longer available. By a regulatory standpoint, IELSG-VTB adheres to the Tubafrost coordinating rule, i.e. if tissue may legitimately be used for research in the country where it was taken out (under whose legal issues the patient falls), it may also be used for research in the country it is sent to [42].

Figure 1 represents a scheme of the VTB. The participating pathologists structure the VTB front-end as a webinterface to allow easy access to data. The VTB is accessible via the IELSG website (www.ielsg.org) in a platformindependent way using any web browser on any operating system (Firefox, Internet Explorer, Safari on Microsoft Windows, Unix or MacOs). No specific software is required at the local pathology institutes. The VTB backend consists of a permanent server placed at the host institute running a Filemaker 7.0 Server Advanced as database engine (FileMaker, Santa Clara, Calif., USA) running on a dedicated Apple G4 desktop computer (Apple, $\mathrm{Cu}$ pertino, Calif., USA) as web server at the IELSG facilities. For security reasons, the server is on a secured intranet connected to the Internet through a dedicated gateway behind a double firewall, separated from the local (hospital) network. SSL (Secure Sockets Layer) encryption for web access is being implemented to further enhance data security. The database can serve up to 100 users simultaneously.

Access to the VTB requires a unique username and a password. Individual usernames and passwords are issued by IELSG after having received a signed agreement form from the pathologists. Username and password are sent to the pathologists by e-mail in two separate messages.

Different levels of access (data submission only and simple statistics vs. full data access) have been implemented. A user defined as collaborator (mostly a pathologist) submits new cases and has read/write access restrict- 


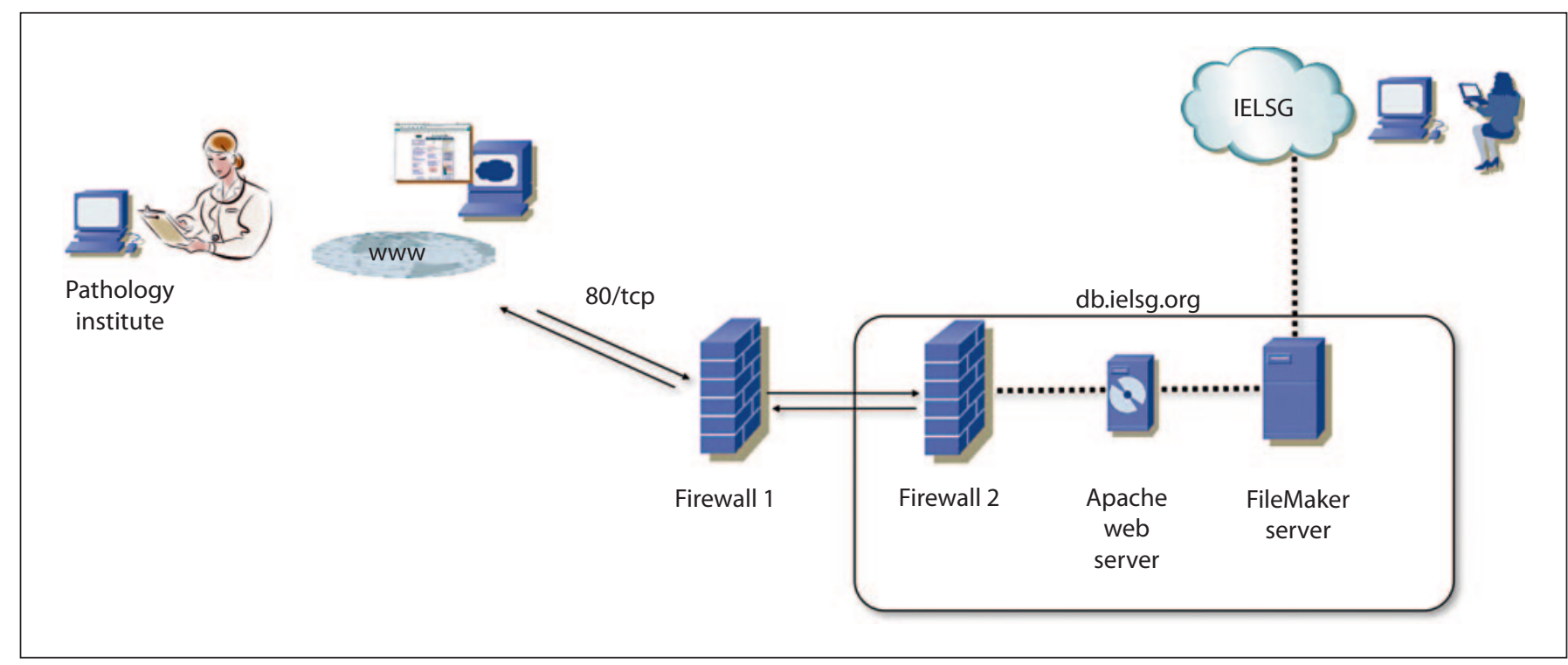

Fig. 1. Scheme of the IELSG-VTB for PCNSL.

Fig. 2. Data collected in VTB.

\begin{tabular}{|c|c|}
\hline Data fioldc & Pathology data \\
\hline Patients data & $\begin{array}{l}\text { - Diagnostic biopsies } \\
\text { - Pathology institute (txt) } \\
\text { - Histology number (No.) } \\
\text { - Site of biopsy (txt) } \\
\text { - Date of biopsy (date) }\end{array}$ \\
\hline $\begin{array}{l}\cdot \text { Date of birth (date) } \\
\text { - Sex }(m / f) \\
\text { - Immunocompetent }(y / n)\end{array}$ & $\begin{array}{l}\text { - Additional histology local number (No.) } \\
\text { - Histology } \\
\text { - Diffuse large cell lymphoma (y/n) } \\
\text { - Burkitt's lymphoma (y/n) } \\
\text { - Marginal zone (y/n) }\end{array}$ \\
\hline Additional data & $\begin{array}{l}\text { - Immunophenotype } \\
\text { - CD20 positive } \\
\text { - CD3 positive }\end{array}$ \\
\hline - Available for tissue array $(y / n)$ & $\begin{array}{l}\text { - Other positive } \\
\text { - Other negative }\end{array}$ \\
\hline - Frozen material available $(\mathrm{y} / \mathrm{n})$ & - First diagnosis (y/n) \\
\hline - Remarks (txt) & - Relapse (y/n) \\
\hline $\begin{array}{l}\text { - Pathologist's name (txt) } \\
\text { - Submission date (date) }\end{array}$ & $\begin{array}{l}\text { - Sample type } \\
\text { - Resection/stereotactic biopsy/ } \\
\text { autopsy/biopsy/other }\end{array}$ \\
\hline
\end{tabular}

ed to his/her own data, and access to basic statistical data on all the registered cases. In other words, investigators will not have direct access to the database, and this approach will be in any case mediated by the Central Office. Access to all the data in the VTB is available only to the curators of the database (M.P. and F.B.), to the bioinformatician (I.K.) and to the IELSG data managers.

The structure of the VTB database has been designed based on our experience with PCNSL and consists mainly of three data types (patient data, pathology data and 
some additional data) anonymously describing patients, pathologies and the availability of samples (fig. 2). Except for the date of birth and sex, personal patient characteristics are not recorded. The local histology number identifies the patient. The pathology data are further subdivided into diagnostic data (i.e. comprising the pathology institute where the diagnosis was made, the date and site of the biopsy, and any additional diagnostic histological sample number), histology (i.e. statistically predominant histotypes or any further histotype), immunophenotype (i.e. 'B' versus ' $T$ ' cell-defining immunophenotypes as well as any further marker tested), the type of the diagnostic sample (i.e. first diagnosis vs. relapse) and the sampling procedure (i.e. stereotactic biopsy vs. surgical resection vs. others). Importantly, information about the presence of frozen material should be included. Database access restrictions have been set in a way that the histology numbers are accessible only to the pathologist who has submitted those data and to the curators and bioinformatician of the VTB and the IELSG data managers. Thus, the pathologist submitting data is the only person who can obtain directly identifiable information on the patient using the local histology number.

Investigators willing to perform research on PCNSL can submit a research project to the IELSG. Each project will be evaluated by the VTB curators for material availability and by the IELSG Review Board for scientific relevance. Once a research project is approved by the IELSG, the VTB curators will put the investigators in contact with the pathologist at the local institutions. The investigators and the local pathologists have to adhere to the lo- cal policies regarding the use of the locally stored pathologic material. Clinical data will be collected only if required for any single project and only after its approval by IELSG; in most instances, these data will regard performance status, lactate dehydrogenase, CSF protein levels, anatomic sites involved and therapeutic regimens. Provided clinical data are usually released to carry out a specific project, in the case of any request of additional data, local clinical services referring to the IELSG will be contacted upon authorization by the latter and, if necessary, by a local ethical committee. The absence of clinical data from the database prevents once again the identification of patients.

Finally, any single project will be evaluated for co-authorship: individual pathologists providing material as well as VTB curators, according to the degree of their own contribution in the investigation; in any case, it must be clearly mentioned in the text that the material for the study has been drawn from VTB.

In conclusion, we have implemented a VTB to explore the availability of PCNSL material for translational studies. We hope this approach might contribute to increase our knowledge on PCNSL and, ultimately, to increase the clinical outcome for patients affected by PCNSL.

\section{Acknowledgments}

We would like to thank Cristina Morinini, IELSG data manager, for her technical expertise. The study was partially supported by an Oncosuisse Grant (No. 01443-12-2003) and a donation from the Leukemia Research Fund, United Kingdom.

\section{References}

1 Zucca E, Roggero E, Bertoni F, Cavalli F: Primary extranodal non-Hodgkin's lymphomas. Part 1: Gastrointestinal, cutaneous and genitourinary lymphomas. Ann Oncol 1997; 8:727-737.

-2 Zucca E, Roggero E, Bertoni F, Conconi A, Cavalli F: Primary extranodal non-Hodgkin's lymphomas. Part 2: Head and neck, central nervous system and other less common sites. Ann Oncol 1999;10:1023-1033.

3 Ferreri AJ, Blay JY, Reni M, Pasini F, Spina M, Ambrosetti A, Calderoni A, Rossi A, Vavassori V, Conconi A, Devizzi L, Berger F, Ponzoni M, Borisch B, Tinguely M, Cerati M, Milani M, Orvieto E, Sanchez J, Chevreau C, Dell'Oro S, Zucca E, Cavalli F: Prognostic scoring system for primary CNS lymphomas: the International Extranodal Lymphoma Study Group experience. J Clin Oncol 2003;21:266-272.
4 Lister A, Abrey LE, Sandlund JT: Central nervous system lymphoma. Hematology Am Soc Hematol Educ Program 2002, pp 283296.

5 Ferreri AJ, Abrey LE, Blay JY, Borisch B, Hochman J, Neuwelt EA, Yahalom J, Zucca E, Cavalli F, Armitage J, Batchelor T: Summary statement on primary central nervous system lymphomas from the Eighth International Conference on Malignant Lymphoma, Lugano, Switzerland, June 12 to 15,2002 . J Clin Oncol 2003;21:2407-2414.

6 6 Ferreri AJ, Dell Oro S, Reni M: Guidelines for the treatment of primary central nervous system lymphomas in immunocompetent patients. Forum (Genova) 2003;13:33-45.

>7 Ferreri AJ, Dell'Oro S, Reni M, Foppoli M, Anzalone N, Govi S, Picozzi P, Truci G, Ponzoni M: Questions and answers in the management of primary central nervous system and ocular lymphomas. Haematologica 2003;88:1063-1068.

-8 Ferreri AJ, Guerra E, Regazzi M, Pasini F, Ambrosetti A, Pivnik A, Gubkin A, Calderoni A, Spina M, Brandes A, Ferrarese F, Rognone A, Govi S, Dell'Oro S, Locatelli M, Villa E, Reni M: Area under the curve of methotrexate and creatinine clearance are outcome-determining factors in primary CNS lymphomas. Br J Cancer 2004;90:353358.

9 Ferreri AJ, Dell'Oro S, Foppoli M, Bernardi $\mathrm{M}$, Brandes AA, Tosoni A, Montanari M, Balzarotti M, Spina M, Ilariucci F, Zaja F, Stelitano C, Bobbio F, Corazzelli G, Baldini L, Ponzoni M, Picozzi P, Caligaris Cappio F, Reni M: MATILDE regimen followed by radiotherapy is an active strategy against primary CNS lymphomas. Neurology 2006;66: 1435-1438. 
10 Nakamura M, Shimada K, Ishida E, Konishi $\mathrm{N}$ : Histopathology, pathogenesis and molecular genetics in primary central nervous system lymphomas. Histol Histopathol 2004; 19:211-219.

-11 Shenkier TN, Blay JY, O'Neill BP, Poortmans P, Thiel E, Jahnke K, Abrey LE, Neuwelt E, Tsang R, Batchelor T, Harris N, Ferreri AJ, Ponzoni M, O’Brien P, Rubenstein J, Connors JM: Primary CNS lymphoma of T-cell origin: a descriptive analysis from the International Primary CNS Lymphoma Collaborative Group. J Clin Oncol 2005;23:22332239.

-12 Ponzoni M, Terreni MR, Ciceri F, Ferreri AJ, Gerevini S, Anzalone N, Valle M, Pizzolito S, Arrigoni G: Primary brain CD30+ ALK1+ anaplastic large cell lymphoma ('ALKoma'): the first case with a combination of 'not common' variants. Ann Oncol 2002;13:18271832.

-13 Braaten KM, Betensky RA, de Leval L, Okada Y, Hochberg FH, Louis DN, Harris NL, Batchelor TT: BCL-6 expression predicts improved survival in patients with primary central nervous system lymphoma. Clin Cancer Res 2003;9:1063-1069.

14 Camilleri-Broet S, Criniere E, Broet P, Delwail V, Mokhtari K, Moreau A, Kujas M, Raphael M, Iraqi W, Sautes-Fridman C, Colombat P, Hoang-Xuan K, Martin A: A uniform activated B-cell-like immunophenotype might explain the poor prognosis of primary central nervous system lymphomas: analysis of 83 cases. Blood 2006;107:190-196.

15 Rubenstein J, Fridlyand J, Shen A, Aldape K, Ginzinger D, Batchelor T, Treseler P, Berger M, McDermott M, Prados M, Karch J, Okada C, Hyun W, Parikh S, Haqq C, Shuman M: Gene expression and angiotropism in primary CNS lymphoma. Blood 2006; 107: 3716-3723.

16 Cobbers JM, Wolter M, Reifenberger J, Ring GU, Jessen F, An HX, Niederacher D, Schmidt EE, Ichimura K, Floeth F, Kirsch L, Borchard F, Louis DN, Collins VP, Reifenberger G: Frequent inactivation of CDKN2A and rare mutation of TP53 in PCNSL. Brain Pathol 1998;8:263-276.

-17 Nakamura M, Sakaki T, Hashimoto H, Nakase H, Ishida E, Shimada K, Konishi N: Frequent alterations of the p14(ARF) and p16(INK4a) genes in primary central nervous system lymphomas. Cancer Res 2001; 61:6335-6339.

18 Rickert CH, Dockhorn-Dworniczak B, Simon R, Paulus W: Chromosomal imbalances in primary lymphomas of the central nervous system. Am J Pathol 1999;155:14451451.

19 Boonstra R, Koning A, Mastik M, Van Den Berg A, Poppema S: Analysis of chromosomal copy number changes and oncoprotein expression in primary central nervous system lymphomas: frequent loss of chromosome arm 6q. Virchows Arch 2003;443:164-169.
20 Sekita T, Tamaru JI, Isobe K, Harigaya K, Masuoka S, Katayama T, Kobayashi M, Mikata A: Diffuse large B cell lymphoma expressing the natural killer cell marker CD56. Pathol Int 1999;49:752-758.

21 Thompsett AR, Ellison DW, Stevenson FK, Zhu D: $\mathrm{V}(\mathrm{H})$ gene sequences from primary central nervous system lymphomas indicate derivation from highly mutated germinal center $B$ cells with ongoing mutational activity. Blood 1999;94:1738-1746.

22 Montesinos-Rongen M, Kuppers R, Schluter D, Spieker T, Van Roost D, Schaller C, Reifenberger G, Wiestler OD, Deckert-Schluter M: Primary central nervous system lymphomas are derived from germinal-center $B$ cells and show a preferential usage of the V4-34 gene segment. Am J Pathol 1999;155:20772086.

23 Montesinos-Rongen M, Van Roost D, Schaller C, Wiestler OD, Deckert M: Primary diffuse large B-cell lymphomas of the central nervous system are targeted by aberrant somatic hypermutation. Blood 2004;103: 1869-1875.

24 Hickey WF: Basic principles of immunological surveillance of the normal central nervous system. Glia 2001;36:118-124.

25 Aloisi F: Immune function of microglia. Glia 2001;36:165-179.

26 Streilein JW: Ocular immune privilege: therapeutic opportunities from an experiment of nature. Nat Rev Immunol 2003;3:879-889.

27 Heppner FL, Prinz M, Aguzzi A: Pathogenesis of prion diseases: possible implications of microglial cells. Prog Brain Res 2001;132: 737-750.

28 Ponzoni $\mathrm{M}$, Berger F, Chassagne-Clement C, Tinguely M, Jouvet A, Iuzzolino P, Cerati M, Carbone A, Weis J, Motta T, Pedrinis E, Milani M, Orvieto E, Sanchez J, Blay JY, Ambrosetti A, Reni M, Vavassori V, Spina M, Calderoni A, Cortelazzo S, Conconi A, Zucca E, Aondio G, Ferrarese F, Gomez H, Ferreri AJM, Cavalli F, Borisch B: Reactive perivascular T-cell infiltrate is an independent favorable prognostic factor in primary central nervous system lymphomas (PCNSL) in immunocompetent patients. Ann Oncol 2002;13:79.

29 Riemersma SA, Jordanova ES, Schop RF, Philippo K, Looijenga LH, Schuuring E, Kluin PM: Extensive genetic alterations of the HLA region, including homozygous deletions of HLA class II genes in B-cell lymphomas arising in immune-privileged sites. Blood 2000;96:3569-3577.

30 Jordanova ES, Philippo K, Giphart MJ, Schuuring E, Kluin PM: Mutations in the HLA class II genes leading to loss of expression of HLA-DR and HLA-DQ in diffuse large B-cell lymphoma. Immunogenetics 2003;55:203-209.
31 Jordanova ES, Riemersma SA, Philippo K, Giphart-Gassler M, Schuuring E, Kluin PM: Hemizygous deletions in the HLA region account for loss of heterozygosity in the majority of diffuse large B-cell lymphomas of the testis and the central nervous system. Genes Chromosomes Cancer 2002;35:38-48.

32 Riemersma SA, Oudejans JJ, Vonk MJ, Dreef EJ, Prins FA, Jansen PM, Vermeer MH, Blok P, Kibbelaar RE, Muris JJ, Schuuring EM, Kluin PM: High numbers of tumour-infiltrating activated cytotoxic $\mathrm{T}$ lymphocytes, and frequent loss of HLA class I and II expression, are features of aggressive $B$ cell lymphomas of the brain and testis. J Pathol 2005;206:328-336.

- 33 Smith JR, Braziel RM, Paoletti S, Lipp M, Uguccioni M, Rosenbaum JT: Expression of B-cell-attracting chemokine 1 (CXCL13) by malignant lymphocytes and vascular endothelium in primary central nervous system lymphoma. Blood 2003;101:815-821.

-34 Anthony IC, Crawford DH, Bell JE: B lymphocytes in the normal brain: contrasts with HIV-associated lymphoid infiltrates and lymphomas. Brain 2003;126:1058-1067.

35 Ferreri AJ, Batchelor T, Zucca E, Cavalli F, Armitage J: International Collaborative Group against Primary CNS Lymphomas. J Clin Oncol 2003;21:1649-1650.

- 36 Oosterhuis JW, Coebergh JW, van Veen EB Tumour banks: well-guarded treasures in the interest of patients. Nat Rev Cancer 2003; 3:73-77.

- 37 Schilsky RL, Dressler LM, Bucci D, Monovich L, Jewell S, Suster S, Caligiuri MA, Kantoff PW, Compton C: Cooperative group tissue banks as research resources: the cancer and leukemia group B tissue repositories. Clin Cancer Res 2002;8:943-948.

38 Malone T, Catalano PJ, O’Dwyer PJ, Giantonio B: High rate of consent to bank biologic samples for future research: the Eastern Cooperative Oncology Group experience. J Natl Cancer Inst 2002;94:769-771.

39 Hair JF, McNicol AM, Gusterson BA: Is research on human tissues at a crossroads? Eur J Cancer 2003;39:2253-2255.

-40 Teodorovic I, Therasse P, Spatz A, Isabelle M, Oosterhuis W: Human tissue research: EORTC recommendations on its practical consequences. Eur J Cancer 2003;39:22562263.

41 Morente MM, Alonso S: Current challenges of human tumour banking. Hematol Oncol 2005;23:54-56.

42 van Veen EB, Riegman PH, Dinjens WN, Lam $\mathrm{KH}$, Oomen MH, Spatz A, Mager R, Ratcliffe C, Knox K, Kerr D, van Damme B, van de Vijver $\mathrm{M}$, van Boven $\mathrm{H}$, Morente MM, Alonso S, Kerjaschki D, Pammer J, Lopez-Guerrero JA, Llombart Bosch A, Carbone A, Gloghini A, Teodorovic I, Isabelle M, Passioukov A, Lejeune S, Therasse P, Oosterhuis JW: TuBaFrost 3: regulatory and ethical issues on the exchange of residual tissue for research across Europe. Eur J Cancer 2006;42:2914-2923. 